\title{
Islamic Perspective to Sharpen Moral Sensitivity of Modern Medicine - The Need for Islamic Code of Medical Ethics
}

\author{
Dhastagir Sultan Sheriff, MS, PhD \\ Benghazi, Libya
}

\begin{abstract}
The advent of newer technologies of heaith care and their adoption have created ethical dilemmas in the minds of physicians. In such a normally turbulent atmosphere drawing guidelines from the Holy Scriptures of different religions may help medicine to serve humanity better. Islam, which is based on the teachings of Alläh (God) as revealed in the Glorious Qur'ān, and on the Sunnah of Prophet Muhammad (PBUH) provides a rich repertoire of scientific, including medical, truths embalmed in ethical guidelines. Projection of such Islamic principles as applied 10 medicine may give a proper ethical dimension to the practice of medicine.
\end{abstract}

Key words: Medical ethics, artificial inethods of reproduction, Islamic teaching, Islamic jurisprudence

DOI: http://dx.doi.org/10.5915/21-2-13314

To write a religious point of view of medicine is a task of immense proportion, as one has to offer an interpretation that is agreeable to a technology-based modern society. While we are living in a society which attempts to rationalize every fact of life, it may prove worthwhile to study the knowledge contained in the Holy Scriptures. In the pursuit of seeking knowledge on a secular basis, science and medicine have advanced to an extent that was once considered impossible. Such possibilities and successes have encouraged scientists to find answers to questions concerning hurnan welfare through scientific enquiry. Without the restraining influence of religion and societal constraints, such freedom has led scientists 10 emphasize only the provision of the comforts of human life.

Religion, which was once part and parcel of every sphere of human activity including science and medicine, now appears to have no moral bearing on scientific thought, direction or development. This

From the Department of Biochemistry Al Arab Medical University

Benghazi, Libya.

Reprint requests: $D$. S. Sheriff

P.O. Box 7025

Benghazi, Libya. has created a secular pluralist society which keeps human welfare segregated from spiritual/religious welfare. Scientific language is secular and supersedes all religious teachings. In this kind of environment it is essential to remember that, like science, religion is a way of life. It has been in existence for ages adding a moral dimension to human society.

We live in a time when more and more of humanity's insoluble problems challenge the medical community and put the physicians in ethical dilemmas. In such a morally confused state it is pertinent to draw the attention of the medical community toward the scientific and moralistic teachings of religious books. The very fact that these religious teachings have remained and shaped the destinies of people throughout history makes the study of the religious point of view of medicine quite relevant.

Recent announcements by some religious bodies that some or all the newly-developed methods of artifical reproduction are unacceptable, reaffirm the need for scientists and medical professionals to consult religious views before advocating controversial methods of medical treatment. It is therefore appropriate to describe the Islamic view of medicine, particularly since religion is an essential part of every human activity of Muslims.

The Holy Qur'ann and the teachings of Prophet Muhammad (PBUH) remain unquestionable truths 
of life for Muslims. Rationalization of the (ranscendental may thus seem unavoidable in order to bring out the salient features of such teachings, for the benefit of the scientific community.

References to these Islamic teachings are derived from the Holy Qur'ān and from the Sunnah which consists of "Ahadith," or oral statements of the Prophet (PBUH), his practice and approvals. The Sunnah, or trodden path, explains and supplements the Holy Qur'ân; the juristic consensus of opinions of all competent jurists after the death of Prophet ('Ijma') is also taken into account.

\section{Islam and knowledge}

Allăh (God) is considered to be a supernatural power who is above human comprehension. Any power which remains above human understanding creates a feeling of wonder or a feeling of awe. Such wonder is thought to be the beginning of understanding. It is also the beginning of worship. As wonder is the first step toward understanding, humility is the first step towards moral maturity. Moral maturity requires the incorporation of a religious perspective. From this religious perspective, Islam teaches that all knowledge takes its roots from the mercy of Allāh:

"Allāh most Gracious. It is He who has taught the Qur'ān. He has created man. He has taught him speech."'

The believers in the Faith (Islam) are motivated to seek knowledge and further their pursuits of knowledge as they are told in a Hadith:

"On Resurrection Day, and whoever walks a path in search of knowledge, Allāh will ease his way to paradise."

\section{Islam and medicine}

Most Muslims jurists were students of medicine. The Prophet Muhammad (PBUH) always considered medicine to be a part of philosophy.

The Prophet (PBUH) has urged the people to seek treatment based on medical science. He said:

"O, Servants of Allāh, seek for medical treatment. Alläh has a remedy for every malady, clear to whoever knows it and unclear to whoever does not know it."'

It is stated that for every illness there is a cure. That cure is intelligible to those who have the right kind of knowledge to understand and practice it. Such a person is a physician.

The Prophet (PBUH) cautioned physicians that such knowledge must not make them think that they are creators; they are only mere vehicles to cure ilInesses. Allāh, the creator, cures illensses through such vehicles.

Allāh says:

". . . Nor can they control Death, nor Life, nor Resurrection."

Personal hygiene, health preservation and rehabilitation are some of the measures advocated and practiced by Prophet Muhammad (PBUH). Personal hygienic measures like ablution before prayer, oral hygiene, and other preventive measures of health, such as cleaniness of body after sex and menstrual period, reflect the importance given to medicine and health by Islam.

\section{Islam and medical ethics}

Adherence to moral principles of Islam is part of the nature of medicine which a physician is required to put into his day-to-day practice of medicine." The cure of an individual patient carries moral responsibilities. Responsibilities make individuals consult their conscience. Commitment to conscience may be directly influenced by true commitment to Allāh. This is emphasized in the Qur'ānic verse:

"Say: "Surely, my prayer and my service of sacrifice, my life and my death are (all) for Allāh, the Cherisher of Worlds."

Islam requires that the physician begin the physical examination, consultation or treatment of the patient in the name of Allah. Islam also states that the physician needs to be patient, choose the right path, always carry a radiant countenance, be kind, compassionate and modest toward the patient. When a male physician examines a woman, he is required to have a female nurse present at the time of his examination.

The Prophet (PBUH) said:

"No man is allowed to be alone with a woman except in the presence of one or two persons."

Prophet Muhammad (PBUH) had greater respect for professional specilization:

"Whoever practices medical treatment without being known to possess the requisite experience would be responsible for the loss suffered by the patient."s

The duty and moral responsibility of the physician towards the patient is given great importance in Islam and is reiterated by the Qur'a nic verse which states:

" $\mathrm{O}$, you who believe, betray not the trust of Alläh 
and the Apostle. Nor misappropriate knowingly things entrusted to you."

To provide better health care and improve the skills of physicians, Islam asks the physician to seek knowledge wherever it is possible. Allāh says:

"... To whom wisdom's granted, receives indeed a benefit overflowing". ${ }^{10}$

Allāh also says:

“... And say, O my Lord! advance me in knowledge." "1

\section{Islam and modern methods of reproduction}

Medicine is a religious necessity of the society. Medical research and development, and introduction of advanced modalities of treatment are essential, but these are to be guided by the principles of Islam.

The methods of artificial reproduction which have been advocated as treatment modalities of infertility need careful scrutiny in the light of Islamic principles. Artificial insemination, in vitro fertilization (IVF), embryo transfer and surrogate motherhood are some of the methods that have gained prominence all over the world.

Islamic jurists guided by Islamic principles declared that artificial insemination of a woman with her husband's sperm, and in vitro fertilization of a wife's ovum with her husband's sperm are acceptable. These methods have been approved in certain Islamic countries, including Saudi Arabia. ${ }^{12}$ They have been advocated as a last biological means to beget a child for a couple when all other modes of trealment have failed. There is general agreement in the Islamic world that such methods could be adopted to fulfill the fundamental right of procreation, if the ovum and spermatozoa subjected to such procedures are to be obtained from a wife and her husband.

After the sprouting of innumerable IVF clinics all over the world, particularly in the West, there seems to be growing concern about the efficiency of these methods reflected by poor rates of fertilization and term pregnancies. Apart from that, the ethical problems created by such issues as (1) the aspiration and fertilization of multiple oocytes, (2) the storage (freezing) and/or disposal of fertilized ova/embryos, (3) the temptation to conduct research on human embryos, and (4) the decision whether or not to conduct embryo biopsies to rule out congenital abnormalities, have led many Western countries to have legislative bodies monitor the activities of these clinics. ${ }^{13}$

In some countries it has been proclaimed that conducting human embryo research is criminal. " While such controversies about these procedures still exist, it appears that their utilization as treatment modalities in Islamic countries is slightly premature. This view is pertinent as these methods are adopted from the Western world and the training to conduct them is imported from those countries.

It is a fact that Islam accords "rights" to a fetus from the time of fertilization and proclaims the sanctity of human life beginning at that stage. Thus, it appears that adopting procedures in which human embryos are manipulated may trangress the fundamental Islamic principle of respecting the rights of an embryo. It is thus necessary to discuss the pros and cons of these procedures by experts of Islamic jurisprudence before an universal decision can be reached for the entire Muslim community. This type of discussion could also prove to be an eye-opener for the whole medical community.

Other areas of ethical concern are abortion (therapeutic or otherwise), contraception and organ transplantation. These topics need to be addressed by experts of Islamic jurisprudence to reach consensus and to recommend certain guidelines to be followed. For example, although therapeutic abortion could be administered primarily to save the mother's life, it can also be performed to avoid giving birth to a child who has chromosomal anomalies, or is at high risk for birth defects following maternal exposure to a known teratogen or to high levels of radiation, as with the nuclear disaster at Chernobyl or if the fetus has been diagnosed to have anomalies by sonography. Guidelines are also needed as to whether contraception could be advocated only as a method to space childbirth, or can it be also used to restrict family size in underdeveloped countries. Guidelines are also needed as to whether Muslim countries can pass laws to restrict the family size. Muslim jurists also are responsible to decide whether brain death can be considered legal death so as to enable organ donation. All these issues need to be addressed carefully. Such decisions by Muslim jurists serve as moral guidelines for medical personnel as well as for patients, to enable them to prudently utilize/undertake currently available, and future, modalities of treatment.

\section{Conclusion}

Science and religion seek values to make human life meaningful and purposeful. Religion is a force that would regulate our activities in society so that these activities become noble and different from animals. Medical science is a fragment of the whole belief in Allāh, from whom everything emanates and ends. Islam believes that all human activities, including medicine, must be guided by the teachings of Alläh inscribed in the Holy Qur'ān. Knowing Islamic principles will not only help the Muslim physician but all those who practice medicine. Thus, it is relevant to focus on the need to include formulation of Islamic principles in medical guidelines or codes of medical 
ethics for the benefit of all humanity.

\section{References}

1. Glorious Qur'ān, Chapter 55, Verses 1-4.

2. Sunan 'Abu Dawūd: "Kitāb al 'Ilm" (Book of Knowledge). Vol. 3, Chapter 1369, p 1034, No.3634 English translation by Ahmed Hassan. Lahore, Pakistan: Sh. M. Ashraf, Kashmiri Bazaar, 1984.

3. Saḥilu Muslim "Kitāb al-Salām" (Book of Salutation and Greetings). Vol. 4, Chapter 924, p 199, No. 5466 English translation by A. H. Siddiqui. Lahore, Pakistan: S. M. Ashraf, Kashmiri Bazaar, 1976.

4. Glorious Qur'ān, Chapter 25, Verse 3.

5. Hathout, H: The Medical Profession - An Islamic Perspective. JIMA 1988; 20:25-32.

6. Glorious Qur'ān, Chapter 6, Verse 162.

7. Sahih Muslim, "Kitāb al-Salām" (Book of Salutation and Greetings). Vol 3, Chapter 908, p
1187, No. 5403, English translation by A. H. Siddiqui. Lahore, Pakistan: S. M. Ashraf, Kashmiri Bazaar, 1976.

8. Sunan 'Abū Dawūd (Arabic) (Book of Diyyat). Chapter 23, 'Izzat al-Da"'ās and 'Ādil al-Sayyid (eds). Hims, Syria: Muhammad 'Ali al-Sayyid, 1972.

9. Glorious Qur'ān, Chapter 8, Verse 27.

11. Glorious Qur'ān, Chapter 2, Verse 269.

12. Glorious Qur'ān, Chapter 20, Verse 114.

12. Abbas S, Wafik, AH, Mahjon, O, Chan R, Itani, S: In vitro fertilization and embryo transfer. Saudi Med J 1987; 8:831-432.

13. Human Fertilization on infertility services and embryo research. Draft legislation on infertility services and embryo research Statutory Licensing Authority. Lancet 1987; 2:1343.

14. Kirk D: West Germany moving to make IVF research a crime. Science 1988; 241:406. 